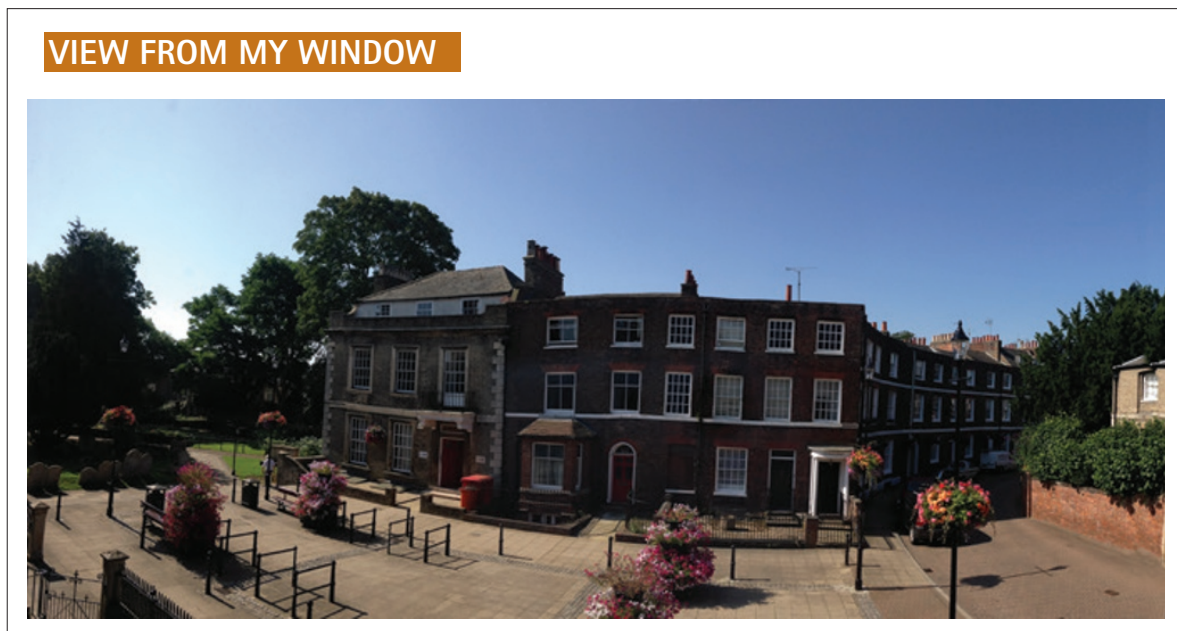

$\mathrm{N}$ ikki Burrell from Wisbech writes: The view from our Georgian Crescent practice is gorgeous. Museum next door, castle opposite and lovely Georgian properties with people walking through to the market square. It has been used for several period productions including the BBC's David Copperfield. With the large double sash windows, the room is a joy to work in. We are a referral practice with patients coming from all areas of Lincolnshire and they are always pleasantly surprised by the beauty in Wisbech'.

\title{
CAUSE FOR APPLAUSE
}

Bridge2Aid is celebrating 10 years of its dental volunteer programme with a black tie dinner at Wembley Stadium on 4 October 2014, from 6.30 pm. Tickets are $€ 95$ per person and include a tour of the grounds, drink on arrival, three-course meal, half a bottle of wine, entertainment and an auction. http://www.bridge2aid.org/birthdaybash/

The President's Dinner held by The Dental Wellness Trust in July at the Royal College of Surgeons raised $£ 34,000$ through ticket sales, pledges and a competitive silent auction. The Trust have also launched the Good:Deed brush to provide toothbrushes for children in need. www.gooddeed.info

Aberfeldy dentists Ross and Morag Anderson have raised over £2,000 for Mary's Meals and Mercy Corps through taking part in the Artemis Great Kindrochit Quadrathlon. The couple came 34th out of 138 teams and were awarded the Trojan prize for best team.
Dr Dharminy Martin from Glynneath Dental Practice in South Wales is running the Cardiff Half Marathon in October in order to raise money for the Mouth Cancer Foundation.

George Morgan and Martin Taylor from Passion Dental Design Studio have raised around $€ 4,000$ for Dentaid. At a launch party held at their new dental laboratory within the historical Red House Glass Cone building, guests were treated to a free evening of verifiable CPD lectures before bidding on a number of generously donated prizes in a charity auction.

Sorabh Patel has rallied a team of 30 denta students from King's College London Dental Institute to take part in the 9th annual Mouth Cancer $10 \mathrm{~km}$ Awareness Walk on 20 September in London's Hyde Park. The team 'Kings Against Cancer' will raise money for the Mouth Cancer Foundation.

\section{HONOURS, AWARDS, APPOINTMENTS}

\section{Shine Award}

The University of Portsmouth Dental Academy has won a Shine Award from Health Education Wessex for its work with school children, isolated young males and vulnerable adults.

Staff were awarded the 'High Performing Education and Training Team of the Year' for their enormous contribution working in and delivering education and training.

\section{ESLO Secretary}

Dr Asif Chatoo has been elected Secretary of the General Council of the European Society of Lingual Orthodontics (ESLO). Dr Chatoo is considered a leading figure in the field and is the only UK orthodontist accredited by both the European and World Societies of Lingual Orthodontics. He founded the UK's first dedicated lingual practice in 2005. 